\title{
Biotin-avidin amplified ELISA for detection of antibodies to Sarcoptes scabiei in chamois (Rupicapra spp.)
}

\author{
Luisa RAMBOZZa ${ }^{\text {a* }}$, Arianna MENZANO ${ }^{\mathrm{a}}$, Santiago LAVIN ${ }^{\mathrm{b}}$, Luca ROSSI $^{\mathrm{a}}$ \\ a Dipartimento di Produzioni Animali, Epidemiologia ed Ecologia, Università di Torino, Italy \\ ${ }^{\mathrm{b}}$ Servei d'Ecopatologia de Fauna Salvatge, Facultat de Veterinaria, \\ Universitat Autonoma de Barcelona, Spain
}

(Received 22 August 2003; accepted 19 May 2004)

\begin{abstract}
Scabies is a major threat to the well being of mountain-dwelling Bovid hosts, Rupicapra rupicapra and Rupicapra pyrenaica. Severe outbreaks are in progress over a significant part of their distribution area and resource managers demand improved methods to monitor, analyse and possibly forecast the spread and effects of scabies at the population level. An amplified capture enzyme-linked immunosorbent assay was developed to detect antibodies to Sarcoptes scabiei in chamois (Rupicapra spp.) serum. The method used the biotin-avidin amplification system and was validated on a panel of 144 serum samples, of which 40 were obtained from scabietic and 104 from healthy unexposed individuals originating from a scabies-free area. The antigen, a whole body extract of the various developmental stages of $S$. scabiei, was prepared from mites actively leaving the skin lesions of naturally infested red foxes (Vulpes vulpes). The resulting LAB-ELISA was characterised by $93 \%$ sensitivity, $97 \%$ specificity and a high degree of repeatibility. A single seroreactor was found amongst 32 chamois affected with skin pathologies other than scabies, including infestations by other Acarina (Trombicula spp. and Ixodid ticks). Antibodies to S. scabiei were present in 26 out of 169 sera $(15.4 \%)$ obtained by clinically healthy chamois within a scabies outbreak area, indicating that asymptomatic infestations by $S$. scabiei can be revealed by serological methods in the studied Caprinae hosts.
\end{abstract}

Sarcoptes / chamois / ELISA / avidin-biotin

\section{INTRODUCTION}

Scabies is a contagious skin disease caused by the mite Sarcoptes scabiei. Man, domestic animals and several captive and freeranging wildlife are affected worldwide [31]. Wild Caprinae are particularly sensitive to Sarcoptes infestation and severe outbreaks of a generalised form of crusty scabies have been reported in chamois (Rupicapra rupi- capra rupicapra and Rupicapra pyrenaica parva) and ibex (Capra ibex ibex and Capra pyrenayca) in southern Europe [15, 24, 33]. Effects on the population are obvious, in fact crude mortality exceeds $90 \%$ on occasions [24, 33]. This is a matter of concern for local authorities and resource managers and there is a demand for careful monitoring of the spread and severity of the outbreaks as well as, possibly, forecasting

\footnotetext{
* Corresponding author: luisa.rambozzi@unito.it
} 
future scenarios. Despite considerable effort by wildlife veterinarians, biologists and field personnel, monitoring scabies outbreaks by means of current methods of investigation (active search for carcasses, observation from distance, direct counts) is a time-consuming, difficult and somewhat indefinite task because of environmental conditions and problems associated with sampling and identifying mite-infested free-ranging animals [28]

In 1991, Boyce et al. [12] showed that antibodies to Psoroptes spp. may be detected in naturally and experimentally infested bighorn sheep (Ovis canadensis) by means of a kinetic immunosorbent assay. The test was subsequently used to determine the distribution of mite-exposed bighorn sheep herds in California [26]. The aim of the screening was to avoid accidental spreading of psoroptic scabies during active relocation programmes. Based on the above experiences, a new serological test - a labelled avidin-biotin immunosorbent assay (LABELISA) - was developed as an aid to epidemiological and pathogenetic studies of Sarcoptes scabies in wild Caprinae in southern Europe.

\section{MATERIALS AND METHODS}

\subsection{Antigen}

Living $S$. scabiei mites at different stages of development and of both sexes were collected from the crusty lesions of naturally infested red foxes (Vulpes vulpes), according to Fisher [17]. Mites were transferred to Eppendorf tubes and stored at $-20{ }^{\circ} \mathrm{C}$ until required.

Mite samples were thawed and washed in $0.1 \mathrm{M}$ carbonate buffer $\mathrm{pH} 7.2\left(\mathrm{Na}_{2} \mathrm{CO}_{3}\right.$ $0.1 \mathrm{M} 33 \%, \mathrm{Na}_{2} \mathrm{HCO}_{3} 0.1 \mathrm{M} 67 \%$ ) containing 1:1000 Tween 20 to eliminate incidental impurity. Then they were filtered out, air dried and weighed. Aliquots of $20 \mathrm{mg}$ mites were homogenised at room temperature in a Griffiths tube with $0.1 \mathrm{M}$ carbonate buffer pH 9.6 and subsequently sonicated five times for $30 \mathrm{~s}$. The ratio of mites to saline in this preparation was approximately $10 \mathrm{mg} /$ $15 \mathrm{~mL}$. The suspension was stirred at $4{ }^{\circ} \mathrm{C}$ for $16 \mathrm{~h}$ and the supernatant was harvested after centrifugation at $18000 \mathrm{~g}$ for $30 \mathrm{~min}$.

The soluble extract was filtered at $0.2 \mu \mathrm{m}$ and the protein concentration, determined by the Lowry method, was adjusted to a concentration of $200 \mu \mathrm{g} / \mathrm{mL}$ in $0.1 \mathrm{M}$ carbonate buffer $\mathrm{pH}$ 9.6. The antigen was stored at $-30{ }^{\circ} \mathrm{C}$ in $1 \mathrm{~mL}$ aliquots.

\subsection{Chamois sera}

Serum samples, obtained from 5 scabietic plus skin-scraping positive chamois from a longtime scabies-endemic area (Eastern Alps, Italy) and 5 healthy unexposed chamois from a scabies-free area (Western Alps, Italy), were initially used to determine optimal assay conditions. According to the repeatability estimate, these sera were later used as control samples during routine runs of the assay.

Once assay conditions were established, 104 sera collected from healthy unexposed chamois (Western Alps, Italy) were used as the negative panel, and 40 sera from scabietic plus skin-scraping positive chamois (21 from the Eastern Alps, Italy, and 19 from the Cordillera Cantabrica, Spain) were used as the positive panel. Out of the scabietic chamois, 14 were mildly affected (less than $10 \%$ of the skin surface showing alopecia and focal hyperkeratotic areas), 18 were moderately affected (diffuse hyperkeratosis and localised thick crusts over 10 $25 \%$ of the skin surface) and 8 were severely affected (thick fissured crusts over up to $40 \%$ of the skin surface). Sera were obtained also from: (i) 32 chamois from scabies-free zones (Western Alps, Italy), showing patent infections of one or more of the following skin pathogens: chiggers (Trombicula spp.; $\mathrm{N}=12$ ), Ixodid ticks (Ixodes ricinus and/or Dermacentor marginatus; 15 ), biting lice (Damalinia alpina; 16), keds (Melophagus rupicaprae; 4), Trichophyton verrucosum (2), Dermatophilus 
congolensis (1) and the Contagious Ecthima virus (3); (ii) 169 healthy chamois from a scabies outbreak area in Auronzo di Cadore (Eastern Alps, Italy). For the sake of brevity, the last ones will be lately cited as "healthy exposed".

Blood was collected from the heart of 246 culled animals (40 healthy unexposed, 25 scabietic, 12 affected with other skin pathologies, 169 healthy exposed); and from the jugular vein of 99 animals (15 scabietic, 64 healthy unexposed, 20 affected with other skin pathologies) captured either chemically or physically using drive nets. After clotting, blood samples were centrifuged at $200 \mathrm{~g}$ for $15 \mathrm{~min}$ and sera were stored at $-20{ }^{\circ} \mathrm{C}$ in $1 \mathrm{~mL}$ aliquots until required.

\subsection{ELISA method}

A $100 \mu \mathrm{L}$ aliquot of the antigen was added to each well of a microtiter plate (TPP ${ }^{\circledR}$ Gamma sterilized), except for the first column where $100 \mu \mathrm{L}$ of carbonate buffer $\mathrm{pH} 9.6$ were added. The plate was left for $40 \mathrm{~min}$ at $37{ }^{\circ} \mathrm{C}$, and subsequently at $4{ }^{\circ} \mathrm{C}$ overnight. Coated like this, the plate was stable for $8 \mathrm{~h}$ at $4{ }^{\circ} \mathrm{C}$; otherwise the plate, incubated for $1 \mathrm{~h}$ in PBS containing 3\% Bovine Serum Albumin and $0.01 \%$ Thiomerosal and stored at $4{ }^{\circ} \mathrm{C}$, is stable for a week.

Each coated well was washed five times in phosphate buffer $\mathrm{pH} 7.2$ containing $0.05 \%$ Tween 20 (SAF-T: $\mathrm{NaH}_{2} \mathrm{PO}_{4} \cdot \mathrm{H}_{2} \mathrm{O}$ $0.18 \%, \mathrm{Na}_{2} \mathrm{HPO}_{4} 1.24 \%, \mathrm{NaCl} 0.85 \%$, Tween $200.05 \%$ ). A $100 \mu \mathrm{L}$ aliquot of serum diluted 1:100 in SAF-T containing 2.0\% Bovine Serum Albumin was added to each well; the plate was then shaken for $1 \mathrm{~h}$ at $37{ }^{\circ} \mathrm{C}$ on a Bellco Mini-Orbital Shaker (Bellco Glass Inc., Vineland, NJ, USA). After five additional washings in SAF-T, $100 \mu \mathrm{L}$ of biotinylated Protein G (Immunopure $^{\circledR}$ Biotinylated Protein G, Pierce Chemical Co., Rockford, IL, USA) diluted $1: 1000$ in sodium acetate buffer $0.1 \mathrm{M}$, pH $5.0\left(\mathrm{C}_{2} \mathrm{H}_{3} \mathrm{O}_{2} \mathrm{Na} \cdot 3 \mathrm{H}_{2} \mathrm{O} 1.4 \%\right)$ was added. The plate was again left one hour at $37{ }^{\circ} \mathrm{C}$, and then washed three times in SAF-T.
A $100 \mu \mathrm{L}$ aliquot of horseradish-peroxidase-labelled Avidin (Immunopure ${ }^{\circledR}$ Avidin Horseradish Peroxidase Conjugated, Pierce Chemical Co., Rockford, IL, USA) diluted 1:10000 in phosphate buffer containing $0.01 \%$ gelatine $\mathrm{pH} 7.2$ was added to each well, and incubated for one hour and washed as before. The plate was washed one time in citrate buffer $0.4 \mathrm{M}$ before the addition of $100 \mu \mathrm{L}$ of substrate solution [2 mM H ${ }_{2} \mathrm{O}_{2}$ 0.2 M ABTS (2,2'-diazino (3 ethilbenz-thiazoline-6-sulfonate), SigmaAldrich Co., St. Louis, MO, USA) $0.4 \mathrm{M}$ citrate $\mathrm{pH} 4.0$ ] to each well. The plate was then incubated for $30 \mathrm{~min}$ at room temperature.

Optical density was read at $405 \mathrm{~nm}$ with a spectrophotometer (Anthos 2010, Anthos Labtec Instruments, Wals, Austria).

\subsection{Performance criteria of the assay}

Assay results were expressed as Optical Density (OD) percentage obtained by the Percent Positivity (PP) method [21, 35], where the OD of each sample tested is expressed as a percentage of a high positive reference standard. This relative measurement results in a uniform and continuous scale of $0-100$ percent positivity, calculated according to the following formula:

OD percentage: OD $(\times)-$ OD (-) / OD (+) - OD (-).

Each sample was assayed in triplicate, to obtain a mean $\mathrm{V}_{\max }$ value; because multiple plates were used, $\mathrm{V}_{\max }$ values on each plate were multiplied by a correction factor, so that between plates comparisons were valid [34]. A correction factor was determined by the following formula: Correction Factor: mean $\mathrm{V}_{\max }$ of SPCS across plates / mean $\mathrm{V}_{\max }$ of SPCS within a given plate, where SPCS means the strong positive control sera.

The intra-plate variability $\left(\mathrm{CV}_{1}\right)$ was estimated by testing the control samples 10 times in triplicate within a particular plate; interplate variability $\left(\mathrm{CV}_{2}\right)$, was assessed by 
Table I. Distribution of the \% OD values of sera obtained from 345 chamois (Rupicapra rupicapra and Rupicapra pyrenaica). The examined cohorts were: healthy unexposed, originating from scabiesfree areas $(\mathrm{N}=104)$; scabietic (40), grouped in three classes according to the severity of skin lesions (mildly affected $=$ less than $10 \%$ of the skin showing alopecia and focal hyperkeratotic areas; moderately affected $=$ diffuse hyperkeratosis and localized thick crusts over $10-25 \%$ of the skin; severely affected $=$ thick fissured crusts over up to $40 \%$ of the skin); affected with skin pathologies other than scabies (32); healthy exposed, originating from a scabies outbreak area (169).

\begin{tabular}{lcccccccccccc}
\hline$\%$ OD & $0-10$ & $11-20$ & $21-30$ & $31-40$ & $41-50$ & $51-60$ & $61-70$ & $71-80$ & $81-90$ & $91-100$ & $101-110$ \\
\hline Healthy unexposed & 7 & 25 & 31 & 25 & 10 & 3 & 1 & 2 & 0 & 0 & 0 \\
Scabietic & 0 & 0 & 0 & 0 & 2 & 3 & 8 & 12 & 11 & 1 & 1 \\
$\quad \begin{array}{l}\text { Mildly affected } \\
\quad\end{array}$ & & & & 1 & 2 & 1 & 6 & 4 & & \\
$\quad \begin{array}{l}\text { Moderately affected } \\
\text { Severily affected }\end{array}$ & & & & & 1 & 2 & 6 & 3 & 4 & 2 & \\
$\begin{array}{l}\text { Skin diseases other } \\
\text { than scabies }\end{array}$ & 2 & 8 & 10 & 8 & 3 & 1 & 0 & 0 & 0 & 0 & 0 \\
Healthy exposed & 14 & 40 & 33 & 30 & 21 & 10 & 9 & 5 & 5 & 1 & 1 \\
\hline
\end{tabular}

comparing the results of the same control samples in five separated assays.

Repeatability was also determined by calculating the amount of agreement using different batches of antigen.

Determination of the cut-off between the positive and negative samples was achieved using the VIFD (Visual Inspection of Frequency Distributions) method, based on frequency distributions of normalised test results from the two panels of samples, positives and negatives. The cut-off value was set at the intersection of the results of the two distributions [20, 27].

The sensitivity and specificity of the assay were calculated according to the following formulae: Sensitivity: True Positive $\times 100 /$ True Positive + False Negative; Specificity: True Negative $\times 100 /$ True Negative + False Positive.

\section{RESULTS}

The distribution of the LAB-ELISA OD values for the sera examined is reported in Table I. Values from the scabietic chamois were significantly higher than those from the healthy unexposed chamois $(74.3 \pm 13.6$ vs. $27.3 \pm 13.4$; $\mathrm{t}=8.96, P<0.001$, MannWhitney U-test). No difference occurred between the sera of 40 chamois allocated to three classes based on scabies severity $(\mathrm{H}=$ 11.59; $P=0.48$, Kruskall-Wallis test).

The cut-off value of the test, found at the intersection of the frequency distributions of sera ODs from healthy unexposed and scabietic chamois, was 55\% (Fig. 1). Based on the selected cut-off, 101 of the 104 sera collected from healthy unexposed chamois had negative OD values (true negatives) and 3 showed positive OD values (false positives); 37 of the 40 sera from scabietic plus skin-scraping positive chamois had positive OD values (true positives) and 3 showed negative OD values (false negatives). The resulting sensitivity was $93 \%$ and the specificity $97 \%$.

A high degree of repeatability was indicated by $\mathrm{CV}_{1}=10 \%$ for triplicate within plates, and a $\mathrm{CV}_{2}=5.8 \%$ for SPCS $\mathrm{V}_{\max }$ across the plates. Correction factors derived from the SPCS values varied from 0.91 to 1.09 .

A single seroreactor was found amongst the 32 chamois affected with skin pathologies other than scabies (a chiggers infested 


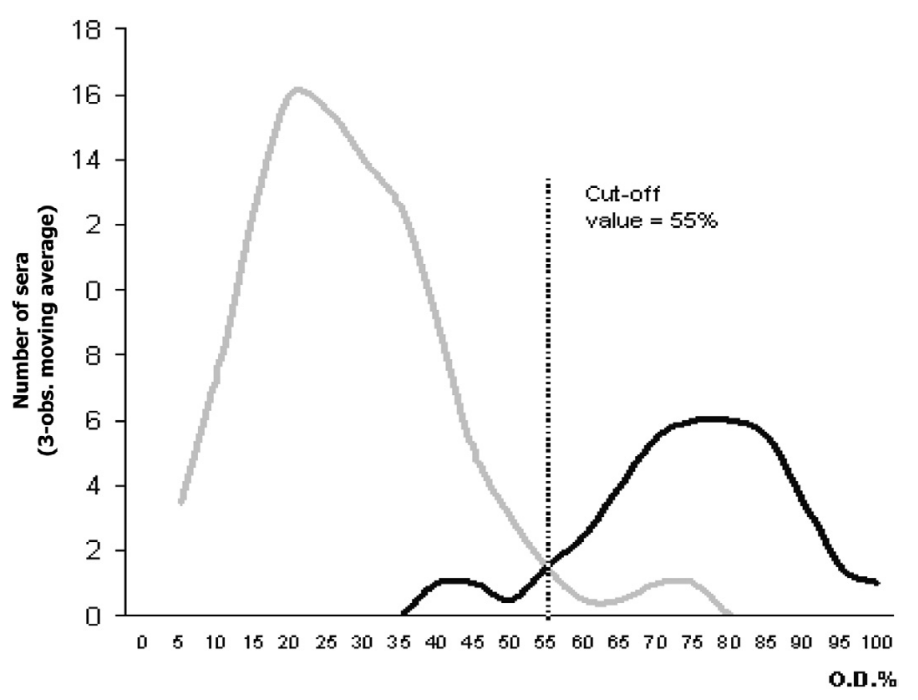

Figure 1. Frequency distribution of \% Optical Density (OD) of sera obtained from scabietic (positive) and healthy unexposed (negative) chamois. The Y-axis represents the number of sera in each 5\% OD interval on the $\mathrm{X}$-axis. The grey line refers to negative sera and the black line to positive sera (3-observations moving average). The broken line represents the cut-off value (55\%) selected from data analysis.

female, which showed a 59\% OD value). OD values from this cohort were similar as those from healthy unexposed ones $(26.4 \pm$ 12.5 vs. $27.3 \pm 13.4 ; \mathrm{z}=0.455, P=0.649$, Mann-Whitney U-test).

A relatively high number of seroreactors was found amongst healthy exposed chamois $(26$ out of $169 ; 15.4 \%)$. The prevalence of seroreactors significantly differed between these chamois, the healthy unexposed ones and those affected with skin pathologies other than scabies $\left(\chi^{2}=13.16 ; P=0.001\right.$, Chi-square test). OD values from healthy exposed chamois were higher $(33.0 \pm 21.4)$ than values from any of the above two cohorts of unexposed individuals but the difference was not significant.

\section{DISCUSSION}

Antibody responses to $S$. scabiei infestation have been documented in domestic and wildlife hosts $[1,3,8]$ and standardised immunosorbent assays are currently available for diagnosis and monitoring of sca- bies in dogs and swine $[9,10,19]$. To the best of our knowledge, the LAB-ELISA described here is the first immunosorbent assay designed for the detection of specific antibodies against $S$. scabiei in a free-ranging ruminant host.

A recognised problem when evaluating a serological test is the availability of one or more gold standards with which to compare the results of the test. This aspect is particularly delicate in the case of dogs and swine, which are prone to develop a hypersentive form of scabies where large mite populations are unlikely to occur [13, 29]. Besides a limited proportion of mite positive individuals, in the above hosts, positives are a heterogeneous group comprising either dogs positively responding to specific treatment [10] or pigs derived from infected farms [19].

In the present study, the positive (infested) and negative (unexposed) status of chamois was objectively reliable. All positives were represented by scabietic chamois testing positive to $S$. scabiei at the skin scraping. 
Negatives were healthy individuals captured in recognised scabies-free zones of northern Italy, some $450 \mathrm{~km}$ west of the closest focus of chamois scabies. It is worth stressing that scabies has a dramatic epidemic course in previously unexposed chamois populations [33]; therefore, there is no chance that such a condition may long remain undetected in a host which is of the outmost interest for thousands of mountain hikers and sport hunters across alpine Europe.

Similarly to Bornstein and Wallgreen [9], the whole body extract of mites obtained from naturally infested red foxes proved a suitable source of antigen. Scabies mites from different host species are morphologically indistinguishable and S. scabiei is generally recognised as a unique species split into physiological varieties, adapted to groups of zoologically related host species [14, 30]. Close similarity between Sarcoptes strains from nine host species (alpine chamois and red fox included) has been confirmed by means of molecular analyses $[5,36]$. Similarly, immunologic cross-reactivity among various strains of scabies mites (var. hominis, canis and suis) has been demonstrated [4]. Scabies is relatively common in red foxes throughout Italy and thousands of mites may be isolated from an individual with generalised crusty lesions. This situation presented us the opportunity to access sufficient quantities of mites for antigen preparation and stock.

The use of recombinant protein $\mathrm{G}$ allowed to overcome the problem of unavailable commercial antisera to our target wild hosts. Previously, recombinant protein $\mathrm{G}$ proved a valuable alternative to secondary antibody in a kinetic ELISA developed for diagnosis of Psoroptes infestation in wild ruminant hosts, Ovis canadensis, Ovis dalli and Cervus canadensis $[11,12,37]$.

The avidin-biotin detection system has the potential to increase the sensitivity of the indirect ELISA since avidin has four binding sites for biotin, making an essentially irreversible complex which is stable in later washes and incubations [22]. We ignore if and how the amplification afforded by the avidin-biotin detection system is crucial to the performance of a SarcoptesELISA working with serum samples but the original decision to include this detection system derived from: (i) the relatively low sensitivity shown by a previously validated non-amplified indirectELISA, when checked in a group of 94 certified Sarcoptesinfected pigs [19]; (ii) the perspective of an application of our test to the measurement of lower specific IgG levels in fluids such as the lung extract, which is more easily available than serum of adequate quality in free-ranging wildlife [16].

Other expected advantages of the avidinbiotin detection system are the low background absorbance and the significant saving of specific antibody or protein G [18].

The choice to select a cut-off by means of the VIFD method is an important element for the adaptation of the assay according to epidemiological requirements; depending on epidemiological purposes - estimating the prevalence of a disease, determining if selected herds have been exposed, assessing the risk of disease transmission between wildlife and domestic hosts, etc. - it may be more important to stress specificity rather than sensitivity, or vice versa, and consequently minimise the number of false positives or false negatives. Compared with other methods, such as the receiver-operator characteristic (ROC) curve, VIFD has the advantage of being simple and flexible, and requires no statistical calculations or assumptions about the normality of the distributions of infected and uninfected reference samples [21].

Overall, the LAB-ELISA permitted a clear definition of the scabies infestation status in chamois. Besides good sensitivity leading to correct identification of even mildly scabietic individuals, a high specificity was demonstrated with samples from a reliable scabies-free area and samples from chamois affected with a variety of skin pathologies which have to be considered in differential diagnosis of scabies. Although 
sera from S. scabiei infested humans and domestic animals are known to cross-react with antigens of other mites, such as the house dust mite Dermatophagoides pteronyssinus [2], our data did not support evidence of cross-reaction with Trombicula spp., which frequently causes skin damage to chamois and other wild ruminants in Europe [6].

Remarkably, specific antibodies could be detected in healthy exposed chamois, suggesting that asymptomatic scabies infestation in this ruminant host can be revealed by the studied ELISA. In other animal models, the presence of asymptomatic seroreactors has been associated to the incubation phase [7], the subclinical course of the infestation [10] or the persistence of antibodies after therapy $[23,25]$. As regards ruminants, persistence of specific antibodies for more than two months after successful treatment with a macrocyclic lactone has been demonstrated in cattle [32]. The possibility to reveal a S. scabiei infestation status in asymptomatic chamois is of a great interest for prospective and retrospective studies assessing the distribution and prevalence of $S$. scabiei infestations in this host and other related wild ruminants suffering from epidemic scabies.

Work is continuing in chamois to ascertain the following: (i) how frequently are specific antibodies detectable in subclinical infestations, involving small numbers of mites; (ii) how soon after exposure are specific antibodies detectable in serum; (iii) how long do antibodies persist in this or related hosts after the disease has eventually self cured or been cured. Information on these factors will be necessary to assess the full potential of the test.

\section{ACKNOWLEDGEMENTS}

The authors are indebted to several persons and agencies: L. Leon Vizcaino, G. Guido, I. Marco, M. Ruiz-Bascaran, P. De Martin, M. Rodolfi, Corpo Forestale dello Stato ex Foresta Demaniale di Tarvisio, Amministrazione Provinciale di Belluno, Parco Naturale Alpi
Marittime, Comprensorio Alpino Alta Valle Susa, Principado de Asturias, Junta de Castilla $y$ Leon. The study was sponsored by the Amministrazione Provinciale di Belluno.

\section{REFERENCES}

[1] Arlian L.G., Runyan R.A., Sorlie L.B., Vyszenski-Moher D.L., Estes S.A., Characterization of Sarcoptes scabiei var. canis (Acari: Sarcoptidae) antigens and induced antibodies in rabbits, J. Med. Entomol. 22 (1985) 321-323.

[2] Arlian L.G., Vyszenski-Moher D.L., Ahmed S.G., Cross-antigenicity between the scabies mite, Sarcoptes scabiei, and the house dust mite, Dermatophagoides pteronyssinus, J. Invest. Dermatol. 96 (1991) 349-354.

[3] Arlian L.G., Morgan M.S., Vyszenski-Moher D.L., Stemmer B.L., The circulating antibody response and induced immunity to scabies, Exp. Parasitol. 78 (1994) 37-50.

[4] Arlian L.G., Morgan M.S., Arends J.J., Immunological cross-reactivity among various strains of Sarcoptes scabiei, J. Parasitol. 82 (1996) 66-72.

[5] Berrilli F., D’Amelio S., Rossi L., Ribosomial and mitochondrial DNA sequence variation in Sarcoptes mites from different hosts and geographical regions, Parasitol. Res. 88 (2002) 772-777.

[6] Boch J., Schneidawind H., Krankheiten des jagdbaren Wildes, Verlag Paul Parey, Hamburg und Berlin, 1988, 398 p.

[7] Bornstein S., Zakrisson G., Humoral antibody response to experimental Sarcoptes scabiei var. vulpes infection in the dog, Vet. Dermatol. 4 (1993) 107-110.

[8] Bornstein S., Zakrisson G., Clinical picture and antibody response in pigs infected by Sarcoptes scabiei var. suis, Vet. Dermatol. 4 (1993) 123-131.

[9] Bornstein S., Wallgreen P., Serodiagnosis of sarcoptic mange in pigs, Vet. Rec. 141 (1997) $8-12$.

[10] Bornstein S., Thebo P., Zakrisson G., Evaluation of an enzyme-linked immunosorbent assay (ELISA) for the serological diagnosis of canine sarcoptic mange, Vet. Dermatol. 7 (1996) 21-28.

[11] Boyce W.M., Zarnke R.L., Antibody responses to Psoroptes sp. mites in Dall sheep (Ovis dalli), J. Wildl. Dis. 32 (1996) 711-713.

[12] Boyce W.M., Mazet J.A.K., Mellies J., Gardner I., Clark R.K., Jessup D.A., Kinetic ELISA for detection of antibodies to Psoroptes sp. (Acari: Psoroptidae) in bighorn sheep (Ovis canadensis), J. Parasitol. 77 (1991) 692-696. 
[13] Cargill C.F., Pointon A.M., Davies P.R., Garcia R., Using slaughter inspections to evaluate sarcoptic mange infestation of finishing swine, Vet. Parasitol. 70 (1997) 191-200.

[14] Fain A., Étude de la variabilité de Sarcoptes scabiei avec une revision des Sarcoptidae, Acta Zool. Pathol. Antverp. 47 (1968) 1-196.

[15] Fernandez-Moran J.S., Gomez S., Ballesteros F., Quiros P., Benito J.L., Feliu C., Nieto J.M., Epizootiology of sarcoptic mange in a population of Cantabrian chamois (Rupicapra pyrenaica parva) in northwestern Spain, Vet. Parasitol. 73 (1997) 163-171.

[16] Ferroglio E., Rossi L., Gennero S., Lung tissue extract as an alternative to serum for surveillance for brucellosis in chamois, Prev. Vet. Med. 43 (2000) 117-121.

[17] Fisher W.F., Precipitating antibodies in sheep infested with Psoroptes ovis (Acarina: Psoroptidae), the sheep scab mite, J. Parasitol. 58 (1972) 1218-1219.

[18] Ginel P.J., Margarito J.M., Molleda J.M., Lopez R., Novales M., Bernadina W.E., Biotin-avidin amplified enzyme-linked immunosorbent assay (ELISA) for the measurement of canine serum IgA, IgG and IgM, Res. Vet. Sci. 60 (1996) 107-110.

[19] Hollanders W., Vercruysse J., Raes S., Bornstein S., Evaluation of an enzyme-linked immunosorbant assay (ELISA) for the serological diagnosis of sarcoptic mange in swine, Vet. Parasitol. 69 (1997) 117-123.

[20] International Organisation for Standardisation (ISO), Quality management and quality assurance standards, Part III: Guidelines for the application of ISO 9001: 1994 to the development, supply, installation and maintenance of computer software. ISO 9003, ISO, Geneva, 1997, 32 p.

[21] Jacobson R.H., Validation of serological assays for diagnosis of infectious diseases, Rev. Sci. Tech. Off. Int. Epizoot. 17 (1998) 469-486.

[22] Kendall C., Ionescu-Matiu I., Dreesman G.R., Utilization of the biotin/avidin system to amplify the sensitivity of the enzyme-linked immunosorbent assay (ELISA), J. Immunol. Methods 56 (1983) 329-339.

[23] Kessler E., Matthes H.F., Schein E., Wendt M., Detection of antibodies in sera of weaned pigs after contact infection with Sarcoptes scabiei var. suis and after treatment with an antiparasitic agent by three different indirect ELISAs, Vet. Parasitol. 114 (2003) 63-73.

[24] Leon-Vizcaino L., Ruiz De Ybanez M.R., Cubero M.J., Ortiz J.M., Espinosa J., Perez L., Simon M.A., Alonso F., Sarcoptic mange in Spanish ibex from Spain, J. Wildl. Dis. 35 (1999) 647-659.
[25] Lower K.S., Medleau L.M., Hnlica K., Bigler B., Evaluation of an enzyme-linked immunosorbant assay (ELISA) for the serological diagnosis of sarcoptic mange in dogs, Vet. Dermatol. 12 (2001) 315-320.

[26] Mazet J.A.K., Boyce W.M., Mellies J., Gardner I., Clark R.K., Jessup D.A., Exposure to Psoroptes $\mathrm{sp}$. mites is common among bighorn sheep (Ovis canadensis) populations in California, J. Wildl. Dis. 28 (1991) 542-547.

[27] McNeil B.J., Keeler E., Adelstein S.J., Primer on certain elements of medical decision making, N. Engl. J. Med. 259 (1975) 211-226.

[28] Meneguz P.G., Rossi L., Sommavilla G.M., De Martin P., Rodolfi M., The most terrible parasitosis of alpine fauna: the sarcoptic mange of chamois, Large Anim. Rev. 2 (1996) 75-83 (in Italian).

[29] Morris D.O., Dunstan R.W., A histomorphological study of sarcoptic acariasis in the dog: 19 cases, J. Am. Anim. Hosp. Assoc. 32 (1996) 119-124.

[30] Pence D.B., Casto S.D., Samuel W.M., Variation in the chaetotaxy and denticulation of Sarcoptes scabiei (Acarina: Sarcoptidae) from wild canids, Acarologia 17 (1975) 160 165.

[31] Pence D.B., Ueckermann E., Sarcoptic mange in wildlife, Res. Vet. Sci. 21 (2002) 385-398.

[32] Rehbein S., Visser M., Winter R., Trommer B., Matthes H.F., Maciel A.E., Marley S.E., Productivity effects of bovine mange and control with ivermectin, Vet. Parasitol. 114 (2003) 267-284.

[33] Rossi L., Meneguz P.G., De Martin P., Rodolfi M., The epizootiology of sarcoptic mange in chamois, Rupicapra rupicapra, from the Italian eastern Alps, Parassitologia 37 (1995) 233-240.

[34] Wright P., Enzyme immunoassay: observations on aspects of quality control, Vet. Immunol. Immunopathol. 17 (1987) 441-452.

[35] Wright P.F., Nilsson E., Van Rooij E.M.A., Lelenta M., Jeggo M.H., Standardisation and validation of enzyme-linked immunosorbent assay techniques for the detection of antibody in infectious disease diagnosis, in: Biotechnology applied to the diagnosis of animal diseases, Rev. Sci. Tech. Off. Int. Epizoot. 12 (1993) 435-450.

[36] Zahler M., Essig A., Gothe R., Rinder H., Molecular analyses suggest monospecificity of the genus Sarcoptes (Acari: Sarcoptidae), Int. J. Parasitol. 29 (1999) 759-766.

[37] Ziccardi M.H., Boyce W.M., Gardner I.A., Seroprevalence of Psoroptes sp. mites in freeranging elk (Cervus elaphus) as determined by kinetic ELISA, J. Wildl. Dis. 32 (1996) $51-56$. 